\title{
著明な石灰化を伴った舌甲状腺例
}

\author{
児玉 章・内田郁 \\ 小澤 博史・片岡 健一*

\section{Lingual Thyroid with Marked Calcification ; A Case Report}

\author{
Akira Kodama, Kaoru Uchida and Hiroshi Ozawa \\ (Shiga University of Medical Science) \\ Ken-ichi Kataoka \\ (Maizuru City Hospital)
}

\begin{abstract}
A 47-year-old female was admitted to our department because of a sensation of foreign body in the throat. After various medical examinations, partial resection of the lingual thyroid was initially planned. However, the tumor was extremely hard and impossible to resect, so total removal of the tumor was performed. The histological diagnosis was "thyroid tissue with hyalinized and calcified stroma without malignancy". Even an extensive search of the literature failed to uncover a case similar to ours.
\end{abstract}

Key words: lingual thyroid, hyalinization, calcification

\section{はじめに}

舌甲状腺症例は，現在までに国内外でそれぞ れ150例余りの報告がある1) 7) が，日常臨床で は稀にしか遭遇しない疾患である。舌甲状腺は 通常軟らかいことが多く8), 手術的治療法では, 部分切除術9), 有茎移植術10111) が行われること が多い，今回我々は，著明な石灰化を伴う非常 に硬い舌甲状腺で, 悪性の可能性も否定できな いために，全摘出術を施行した症例を経験した ので，文献的考察を加光報告する.

\section{症例}

患者：47歳，女性.

主訴：咽頭異物感.

現病歴: 約 5 年前頃より, 咽頭部の圧迫感を
時々自覚していた. 平成 2 年秋頃より咽頭異物 感が増強するも放置. 平成 3 年 3 月, 感冒のた め近医耳鼻咽喉科を受診した際に舌根部の腫瘤 を指摘された。平成 3 年11月, 精査加療の目的 で当科に紹介受診となった。

既往歴：前頸部腫瘤の摘出術 ( 7 歳時), 気管 支喘息 (42歳時).

家族歴：特記することなし.

初診時所見：舌圧子で舌根部を圧迫すると， 直径約 $2.5 \mathrm{~cm}$, 表面は注济平滑でやや暗赤色, 弾性硬の腫瘤が, 半球状に突出して認められ た.腫瘍の表面には, 数本の細い血管を認めた （図 1). 身長 $150 \mathrm{~cm}$, 体重 $46 \mathrm{~kg}$ で, 精神発達 遅滞などはない。また舌骨上の前頸部正中に約 
$4 \mathrm{~cm}$ の手術瘢痕を認めた。

血液検査では, TSH とサイログロブリンの 高值, $\mathrm{T}_{4}$, 遊離 $\mathrm{T}_{3}$, 遊離 $\mathrm{T}_{4}$ の軽度低值を示し た. サイロイドテスト，マイクロゾームテスト は陰性, 炎症反応は認められなかった（表 1)。 咽頭側面 X線では, 舌根部の腫瘤に一致して,

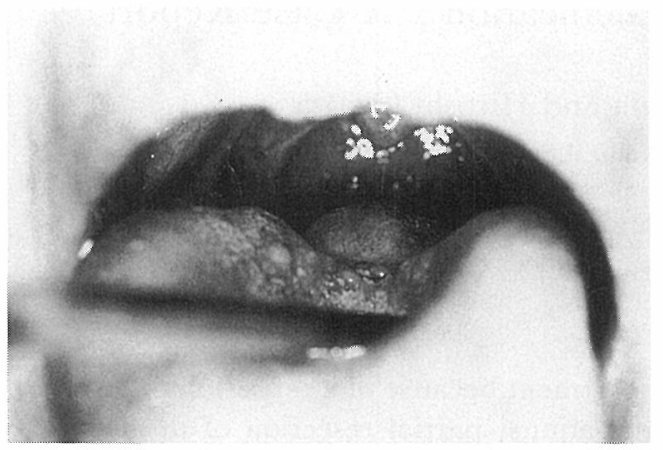

図 1 局所所見

舌根部に直径 $2.5 \mathrm{~cm}$, 半球状の腫瘤を認める.

表 1 検查成績

\begin{tabular}{clcl}
\hline \hline 血液一般 & \multicolumn{3}{c}{ 生化学検査 } \\
HT & $37.4 \%$ & TP & $6.0 \mathrm{~g} / \mathrm{dl}$ \\
$\mathrm{HB}$ & $12.7 \mathrm{~g} / \mathrm{dl}$ & $\mathrm{A} / \mathrm{G}$ & 2.75 \\
$\mathrm{RBC}$ & 397 万 & $\mathrm{CHO}$ & $188 \mathrm{mg} / \mathrm{dl}$ \\
WBC & 7,500 & $\mathrm{GOT}$ & $14 \mathrm{IU} / 1$ \\
$\mathrm{PLTS}$ & 157,000 & $\mathrm{GPT}$ & $14 \mathrm{IU} / 1$ \\
血液像 & 正常 & $\mathrm{LDH}$ & $312 \mathrm{IU} / 1$ \\
& & $\mathrm{Ca}$ & $8.3 \mathrm{mg} / \mathrm{dl}$ \\
& & $\mathrm{P}$ & $3.8 \mathrm{mg} / \mathrm{dl}$ \\
& & $\mathrm{CRP}$ & $0.0 \mathrm{mg} / \mathrm{dl}$
\end{tabular}

血清

$\begin{array}{ll}\text { サイロイドテスト } & \text { 陰性 } \\ \text { マイクロゾームテスト } & \text { 陰性 }\end{array}$

甲状腺機能検査

(正常值)

$\begin{array}{lll}\text { TSH } & 79.40 \mu \mathrm{IU} / \mathrm{ml} & (0.1 \sim 4.0) \\ \mathrm{T}_{4} & 4.1 \mu \mathrm{g} / \mathrm{dl} & (4.7 \sim 11.8) \\ \mathrm{T}_{3} & 0.87 \mathrm{ng} / \mathrm{ml} & (0.7 \sim 2.1) \\ {\mathrm{F}-\mathrm{T}_{4}} & 0.6 \mathrm{ng} / \mathrm{dl} & (0.8 \sim 2.1) \\ \mathrm{F}^{-} \mathrm{T}_{3} & 1.8 \mathrm{pg} / \mathrm{ml} & (2.8 \sim 6.0) \\ \mathrm{TBG} & 19.1 \mu \mathrm{g} / \mathrm{ml} & (12 \sim 30) \\ \mathrm{H}-\mathrm{TG} & 320.0 \mathrm{ng} / \mathrm{ml} & (40 \text { 以下) } \\ \text { TRAB } & 11.0 \% & (15 \text { 以下 })\end{array}$

粗大および微小な石灰化像を認めた(図 2).

図 3 亿造影 CTを示す. 舌根部に石灰化を伴 い, 周囲組織との境界は明膫で咽頭に突出する, 直径 $2.5 \mathrm{~cm}$ の円形の腫瘤を認めた.

MRI では腫瓷は, T1 強調像では筋肉と等信 号で内部に一部高信号域を, T2 強調像では低

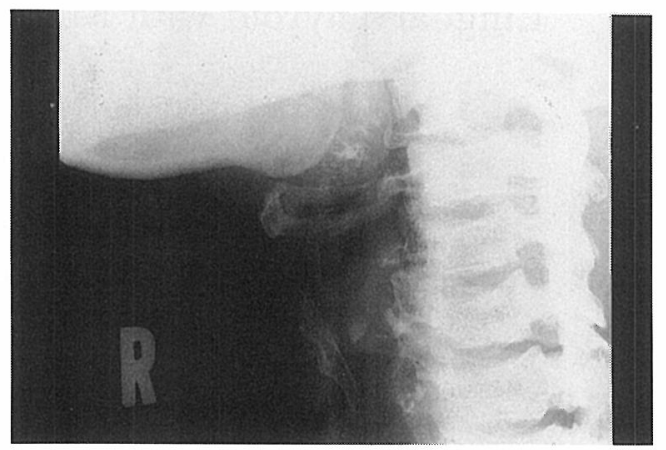

図 2 咽頭側面X線 舌根部の腫瘤に石灰化像を認める.

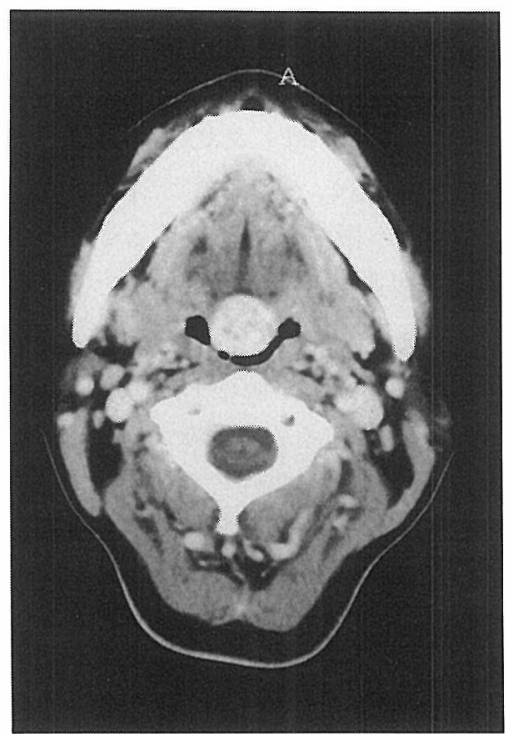

図 3 造影 CT

周囲組織との境界は明瞭である。 
信号で内部に一部高信号域を認め, 甲状腺組織 と一部の強い線維化が考えられた。

$99 \mathrm{~m} \mathrm{Tc}$ シンチグラムでは, 舌根部の腫瘤と甲 状腺左葉の一部に集積を認めたが，甲状腺右葉 には集積を認めなかった(図 4).123I シンチグ ラムでも同様の像で，舌根部に $12.20 \%$, 頸部 甲状腺左葉に $2.17 \%$ の取り込久を認めた。超音 波検査でも $2 \times 3 \mathrm{~cm}$ の甲状腺左葉が確認され た。

以上の検査結果から，甲状腺左葉を有し，著 明な石灰化を伴う舌甲状腺と診断し，平成 3 年 12月 2 日手術を施行した。術式は，軽度の甲状 腺機能低下状態にあったため，口腔内からの腫 瘤部分切除術を予定した。しかし，腫瘤は術前 の予想よりも硬く，メスやレーザーメスでの切
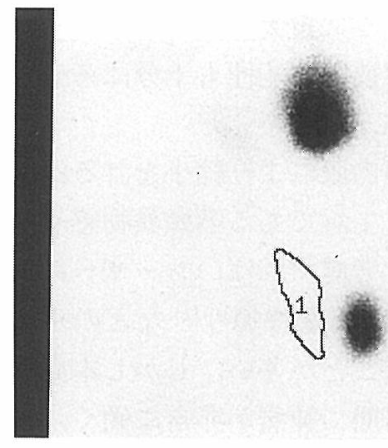

図 $499 \mathrm{~m} \mathrm{Tc}$ シンチグラム

舌根部と固有甲状腺の左葉の一部に集積を認める。

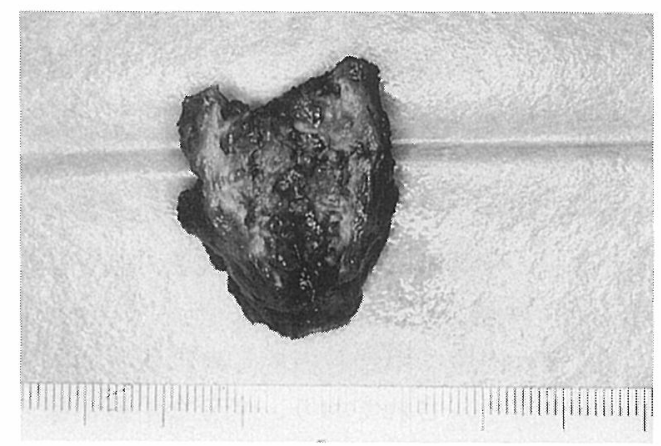

図 5 摘出標本の割面 灰白色の部分を一部に認める.
除，蒸散は困難であり，仮に腫瘤の部分切除を 行ってもこの硬さでは主訴の咽頭異物感は軽快 しないと予想され，また悪性の可能性も完全に は否定できないこともあり，腫瘤の全摘出術と した。術中，一時動脈性の激しい出血をみたが， 結紮ならびに電気凝固処置にて止血した。術中 の出血量は $630 \mathrm{ml}$ であった。術後の舌根部腫 脹の可能性を考慮し，気管切開を施行した。こ の際気管上には甲状腺組織は認めず，また甲状 腺左葉はこの術野では確認できなかった。

図 5 亿摘出標本の割面を示す. $2.5 \times 3 \mathrm{~cm}$ で, メスで辛うじて切開可能な汪ど非常に硬く, 内 部には一部灰白色の部分も認めた。

病理組織学的には, ヒアリン化を伴う増生し た結合織の中に石灰化像を，また一部には大小 様々の甲状腺濾胞を認め, ヒアリン化と石灰化 を伴う甲状腺組織であったが，核の異型性は認 められなかった（図 6).

気切口は, 術後 7 日目に閉鎖し, 咽頭異物感 は術後約 3 週目頃に消失した。 また術後粘液水 腫，テタニーなどの症状は出現せず，術後 1 力 月目の甲状腺機能検査は TSH $21.4 \mu \mathrm{IU} / \mathrm{ml}$, $\mathrm{T}_{3} 1.4 \mathrm{ng} / \mathrm{ml}, \mathrm{T}_{4} 4.5 \mu \mathrm{g} / \mathrm{dl}$ であったが, 術後 3 カ月目では TSH の上昇傾向を認め, 軽度の 甲状腺機能低下状態となったため, 現在チラー ジン $\mathrm{S}^{\circledR} 50 \mu \mathrm{g} /$ 日の内服で, 通院加療中である.

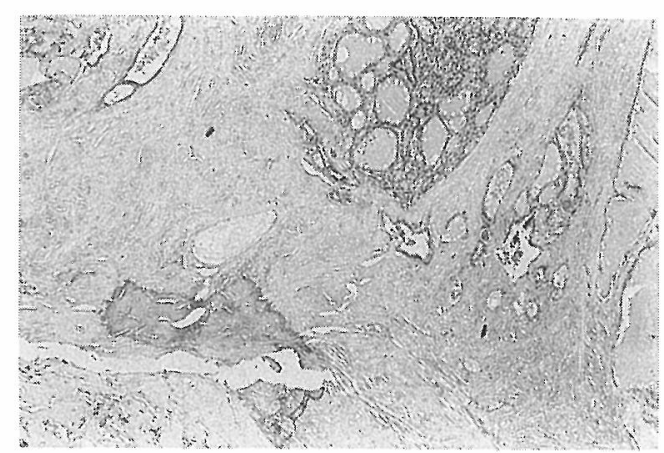

図 6 病理組織所見

ヒアリン化を伴う増生した結合織の中に石灰化像 を認める。.甲状腺滤胞も認める。 


\section{考案}

舌甲状腺は，甲状腺の発生過程での原基の下 降不全や迷入により生じ，現在までに国内・国 外でそれぞれ150例余りの報告がある1) 7). 舌 甲状腺の発生例数は, 甲状腺疾患患者の 3,000 例に 1 例程度 3 ) と報告されているが, 甲状腺シ ンチグラムの普及により, 発生頻度は増加する 傾向にある1) といら．以下表 2 に，これまでの 報告による舌甲状腺の特徵を要約して示す。今 回の我々の症例は, 47歳女性で, 舌甲状腺と固 有甲状腺の半葉を有する症例で，奥村ら ${ }^{8)}$ の報 告と類似の症例であった. しか子幼少時に摘出 を受けた前頸部の腫瘤を本人は“ろくろ”と記 憶して沶り，正中頸襄腫を併発していた可能性 もあり，臨床的には珍しい症例と考えられる。

従来の報告との相違点は, 我々の症例の舌甲 状腺の腫瘤は非常に硬く, 組織学的にもヒアリ ン化，石灰化が著明であった点があげられる.

これまでの舌甲状腺の報告では，腫瘤は弾性軟 で軟らかいことが多い8) とされ，本症例のごと く舌甲状腺の石死化の記載があったのは小森 $5^{12)}$ ，八木ら13) の報告のみである. 病理学的 には，ヒアリン化は様々な型の甲状腺炎や腺腫 様甲状腺腫の場合に，甲状腺間質結合織にしば

表 2 舌甲状腺の特徵

1. 初診時年齢, 性

思春期，青壮年期，妊娠中に多く，20歳衣 でで約50\%

男:女 $=1: 5 \sim 7$

2 . 甲状腺との関係

固有の甲状腺が，ある：10\%，ない: 60〜 $80 \%$

3. 甲状腺機能

正常 : 33\%, 低下 : 25～40\%

4. 症状

咽頭異物感, 咽頭痛, 嚥下困難, 呼吸困難, 大出血, 精神発達遅滞, クレチニズム

5. 治療

保存的：甲状腺剂の投与

手術的：全摘出, 部分切除, 移植

（遊離または有茥）
しば認められ ${ }^{14)}$ ，また石灰化は変性壊死に陥っ た組織に好んで生じる15)といわれる，咀嚼・ 嚥下時の反復刺激による反応性炎症に起因寸

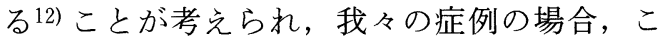
れが長期間に及んだことが原因と考兄られる。

臨床的にみると甲状腺組織の石灰化の有無に より腫瘍の良性, 悪性を判定することは困難で あるが，石灰化先のものは良性腫瘍よりも悪性 腫瘍に認められることが多い16). 舌甲状腺の悪 性化は，通常の甲状腺に比べ特に多いものでは ない5)とされるが, Montgomery3)4) は144例中 4 例に, Fish ら5) は, 1910年から1958年まで の間に21例に, Kamat $ら^{6)}$ は12例中 2 例に, それぞれ舌甲状腺に悪性所見を認めたと報告し ている。また国内では八木ら13)が，石灰化を 伴った舌甲状腺に濾胞癌が生じた症例を報告し て括り，本症例のように粗大招よび微小な石灰 化像を認めれば，悪性の可能性も十分に考慮し て抎かねばならない。

治療は甲状腺剤の内服により縮小を計る保存 的な方法もあるが，主訴である咽頭異物感や， 出血を来す可能性を考慮すれば，レーザーによ る蒸散や部分切除 ${ }^{9)}$, 有茎移植1011) などの手術 的な方法がとられることが多い。しかし本症例 のよらに石灰化が著明で腫瘤が非常に硬く, 主 訴の咽頭異物感などの臨床症状が部分切除では 消失しない可能性が高く，また悪性の可能性も 否定できない場合には，部分切除や有茎移植よ りは全摘出術の適応と考える. 手術法としては, 口内法の他, 咽頭側切開も考兄られるが，腫瘤 の大ささ，部位を考慮し，本症例では口内法に よる全摘出術とした．術中の出血はやや多くな ったが，術後の呼吸困難や粘液水腫などの合併 症もなく, 術後 7 力月経過した現在, 強かった 咽頭の異物感も完全に消失し，チラージン $\mathrm{S}^{\circledR}$ $50 \mu \mathrm{g}$ / 日の内服で甲状腺機能も浪涪正常範囲内 にコントロールされており，十分な手術治療の 効果があったと考えている。 


\section{まとめ}

著明な石灰化を伴った舌甲状腺の症例を報告 した．腫瘤は非常に硬く部分切除は不可能であ り，咽頭異物感も強く，また悪性も否定できな かったため, 全摘出術を行った. 病理組織学的 には，ヒアリン化と石灰化を伴ら舌甲状腺であ った．本症例のように，高度の石灰化を伴った 非常に硬い舌甲状腺の報告はこれまでにはなく， ここに報告した.

本論文の一部は, 第51回日本耳鼻咽喉科学会京都 滋賀合同地方部会 (平成 4 年 4 月, 京都市)に拉いて 口演した.

\section{参考文献}

1）佐藤言葉, 田川俊郎, 中川英俊, 他 : 舌甲状腺 の 1 症例ならびにその文献的考察. 日口外誌 $31: 62 \sim 67,1985$.

2）伊藤恵子, 山下耕太郎, 古川 滋, 他：舌甲状 腺の 1 症例. 耳鼻 $35: 21 \sim 36,1989$.

3) Montgomery ML : Lingual thyroid; a comprehensive review. West J Surg $43: 661 \sim 669$, 1935.

4) Montgomery ML : Lingual thyroid; a comprehensive review. West J Surg $44: 54 \sim 62$, 122 128, 189 195, 237 247, 303 309, 373 379, 442 446, 1936.

5) Fish J and Moore RM : Ectopic thyroid tissue and ectopic thyroid carcinoma ; a review of the literature and report of a case. Ann Surg $157: 212 \sim 222,1963$.

6) Kamat MR, Kulkarni JN, Desai PB, et al : Lingual thyroid; a review of 12 cases. $\mathrm{Br} \mathrm{J}$
Surg $66:$ 537 539, 1979.

7) Weider DJ and Parker W : Lingual thyroid; review, case reports, and therapeutic guidelines. Ann Otol Rhinol Laryngol 86 : 841 848, 1977.

8）奥村隆史, 大川内一郎, 松永 亭, 他 : 甲状腺 片葉欠損を伴った舌根部甲状腺腫. 耳喉 57 : 197 200, 1985.

9）松岡秀隆, 上村正行, 栗田茂二郎, 他 : 舌根甲 状腺の一症例. 耳鼻 $29: 471 \sim 476,1983$.

10）小宮山荘太郎, 原田好雄, 牧嶋和見: 舌根甲状 腺移植術症例. 耳鼻 $18: 46 \sim 49,1972$.

11）小川 明, 山下公一, 宮崎 巨, 他 : 舌根甲状 腺の手術療法. 日耳鼻 $90: 1359 \sim 1362,1987$.

12）小森常喜, 石井保雄 : 舌甲状腺の 1 症例. 日口 外誌 $28: 160 \sim 163,1982$.

13）八木正人, 立本圭吾, 安田範夫, 他 : 舌根甲状 腺に発生した濾胞癌症例. 耳鼻臨床 84 : 975〜 980, 1991.

14）中川定明 : 変性. 壊死. 萎縮. 現代病理学大系 17A(飯島宗一，他編). 293～300頁，中山書店， 東京, 1988 .

15）岩政輝男, 内野文彌, 土山秀夫 : 退行変性. 病 理学(遠城寺宗知編). $7 \sim 62$ 頁, 医学書院, 東 京, 1989 .

16）東 与光, 伊藤国彦, 西川義彦: 軟 $\mathrm{X}$ 線撮影に よる甲状腺腫の石灰化像. 臨放 $29: 869 \sim 873$, 1984.

\footnotetext{
(原稿受付: 平成 4 年 9 月 3 日 原稿採択 : 平成 4 年10月19日 別刷請求先 : 児玉 章 干520-21 大津市瀬田月輪町 滋賀医科大学耳鼻咽喉科学教室
} 